\title{
Editorial
}

\section{Malaysian Journal of Medical Sciences' Performance Status in 2016}

\author{
Nour AzImah Zulkapli', Jafri Malin Abdullah²
}

Submitted: 21 Nov 2017

Accepted: 29 Nov 2017

Online: 29 Dec 2017
1 Production Editor, Malaysian Journal of Medical Sciences, Universiti Sains Malaysia, 11800 USM, Pulau Pinang, Malaysia

2 Chief Editor, Malaysian Journal of Medical Sciences, Universiti Sains Malaysia Health Campus, 16150 Kubang Kerian, Kelantan, Malaysia

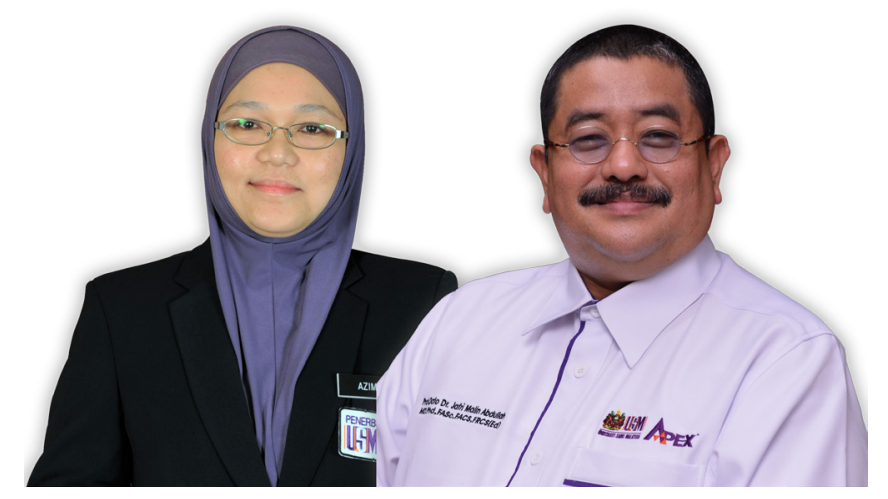

To cite this article: Nour Azimah Z, Jafri Malin A. Malaysian Journal of Medical Sciences' performance status in 2016. Malays J Med Sci. 2017;24(6): 1-4. https://doi.org/10.21315/mjms2017.24.6.1

To link to this article: https://doi.org/10.21315/mjms2017.24.6.1

\begin{abstract}
This editorial aims to report on the performance of the Malaysian Journal of Medical Sciences (MJMS) in the year 2016. The performance report is based on an analysis of the autogenerated data compiled from the ScholarOne Manuscripts ${ }^{\mathrm{TM}}$. It will specifically focus on the pattern of manuscript submission, geographical distribution of contributors, manuscript submission by month and the acceptance-rejection rate of post-review manuscripts. It will also discuss the effects of the decision to raise the article acceptance standards.

The MJMS would also like to share the news of its receipt of the 2016 Current Research in Malaysia (CREAM) award. This honour was bestowed upon us by the Ministry of Higher Education (MOHE) of Malaysia, on November 1, 2016.
\end{abstract}

Keywords: Malaysia, geographic factors, metadata, awards and prizes

\section{Introduction}

The total number of original manuscripts submitted online to the Malaysian Journal of Medical Sciences (MJMS) appears to be increasing from year to year. In 2016 alone, MJMS received 301 manuscripts compared to 272 manuscripts in the previous year, an increase of $9.63 \%$ (1).

Despite the rising annual number of submissions, the annual number of rejections has also increased. This has mainly resulted from the pre-review screening phase, and was due to the inappropriateness of the content of some of the research submitted. However, the rejection of manuscripts following peer review also contributed to the growth of the rejection rate, due to a more stringent control of the quality of the research and the presentation of the content. The final judgement, after all, was made by the Editor-in-Chief based on our reviewers' comments. 
It is hoped that, in future, authors will be able to scrutinise the manuscript preparation guidelines and comply with MJMS' standards and regulations before they proceed with the submission process. This could probably save us from having to return manuscripts back to authors when their preparation is not in accordance with the journal guidelines. It may even shorten the duration of pre-review screenings.

\section{Pattern of Manuscript Submission}

As demonstrated in Table 1, the most frequently submitted manuscripts were Original Manuscripts, with a total number of 213 submissions. They were followed by 35 submissions of Review Articles, 26 submissions of Brief Communications, 11 submissions of Special Communications and 8 submissions of Case Reports and Editorials.

Although MJMS has not been accepting new Case Report manuscripts since 2016, it still received a number of new Case Report submissions, which were subsequently rejected.

Table 1. Original manuscripts submitted via ScholarOne Manuscripts ${ }^{\mathrm{TM}}$ between Jan 1, 2016 and Dec 31, 2016, by type.

\begin{tabular}{lccc}
\multicolumn{1}{c}{$\begin{array}{c}\text { Manuscript } \\
\text { Type }\end{array}$} & Original & Revised & Total \\
$\begin{array}{l}\text { Brief } \\
\text { communications }\end{array}$ & 26 & 0 & 26 \\
Case reports & 8 & 0 & 8 \\
Editorial & 8 & 0 & 8 \\
Original article & 213 & 0 & 213 \\
Review articles & 35 & 0 & 35 \\
Special & 11 & 0 & 11 \\
$\quad$ communications & & & \\
\hline Total & $\mathbf{3 0 1}$ & $\mathbf{0}$ & $\mathbf{3 0 1}$ \\
\hline
\end{tabular}

Source: https://mc.manuscriptcentral.com/maljms

\section{Geographical Distribution of Contributors}

As expected, Malaysian authors were the main contributors of MJMS manuscripts, with 121 submissions (equivalent to $40.2 \%$ ). The top foreign contributors from Asian region were India (18.6\%), Iran (13.3\%), Indonesia (6.6\%) and Saudi Arabia (2.3\%). Additionally, Nigeria was the only non-Asian country to contribute heavily (Table 2).
Table 2. Original manuscripts submissions via ScholarOne Manuscripts ${ }^{\mathrm{TM}}$ by country of submission between Jan 1, 2016 and Dec 31, 2016

\begin{tabular}{|c|c|c|}
\hline $\begin{array}{c}\text { Country of } \\
\text { Submitting } \\
\text { Author }\end{array}$ & $\begin{array}{l}\text { Number of } \\
\text { manuscripts } \\
\text { submitted }\end{array}$ & Percentage \\
\hline Malaysia & 121 & $40.2 \%$ \\
\hline India & 56 & $18.6 \%$ \\
\hline $\begin{array}{l}\text { The Islamic } \\
\text { Republic of Iran }\end{array}$ & 41 & $13 \cdot 3 \%$ \\
\hline Indonesia & 20 & $6.6 \%$ \\
\hline Nigeria & 16 & $5 \cdot 3 \%$ \\
\hline Saudi Arabia & 7 & $2.3 \%$ \\
\hline Algeria & 3 & $1.0 \%$ \\
\hline Italy & 3 & $1.0 \%$ \\
\hline Pakistan & 3 & $1.0 \%$ \\
\hline Palestine, State of & 3 & $1.0 \%$ \\
\hline Thailand & 3 & $1.0 \%$ \\
\hline Turkey & 3 & $1.0 \%$ \\
\hline Vietnam & 3 & $1.0 \%$ \\
\hline Brunei Darussalam & 2 & $0.7 \%$ \\
\hline Cuba & 1 & $0.3 \%$ \\
\hline Germany & 1 & $0.3 \%$ \\
\hline Ghana & 1 & $0.3 \%$ \\
\hline Iraq & 1 & $0.3 \%$ \\
\hline Kazakhstan & 1 & $0.3 \%$ \\
\hline Lebanon & 1 & $0.3 \%$ \\
\hline Nepal & 1 & $0.3 \%$ \\
\hline Russian Federation & 1 & $0.3 \%$ \\
\hline Singapore & 1 & $0.3 \%$ \\
\hline Sri Lanka & 1 & $0.3 \%$ \\
\hline Sudan & 1 & $0.3 \%$ \\
\hline $\begin{array}{l}\text { United Kingdom of } \\
\text { Great Britain and } \\
\text { Northern Ireland }\end{array}$ & 1 & $0.3 \%$ \\
\hline United States & 1 & $0.3 \%$ \\
\hline Yemen & 1 & $0.3 \%$ \\
\hline Summary & 301 & $100 \%$ \\
\hline
\end{tabular}

Source: https://mc.manuscriptcentral.com/maljms

The data from author's affiliation and country were used to measure foreign contributions, and became evidence that international authors are publishing their works in Malaysian journals (2). Even though the number of foreign contributors is comparatively small, it can be used to infer that authors from these regions trust MJMS with publishing their findings. 
Editorial | Malaysian Journal of Medical Sciences' Performance Status in 2016

\section{Manuscript Submission by Month}

Figure 1 gives a summary of the total number of manuscripts submitted in 2016, on a monthly basis. The highest total number of submissions received by MJMS was 32 manuscripts in April, 30 manuscripts in March and 29 manuscripts in January. The number of manuscript submission in the following months did not vary significantly, however.

The high number of submissions during the first quarter of 2016 might indicate that authors had their finalised findings on hand and were ready to submit their manuscripts at that time. Some of them had even submitted their manuscripts twice or more, with their names listed as either a main author or a co-author.

\section{The Acceptance-Rejection Rate of Post- Review Manuscripts}

Figure 2 depicts the status of post-review manuscripts received in 2016 following the decision, made by the Editor-in-Chief based on collective comments, to raise the quality standards for manuscript acceptance. Out of 208 manuscripts with a decision, only 4 (1.9\%) post-review manuscripts were accepted for publication, 70 (33.7\%) needed major revision and $32(15.4 \%)$ needed minor revision. A total

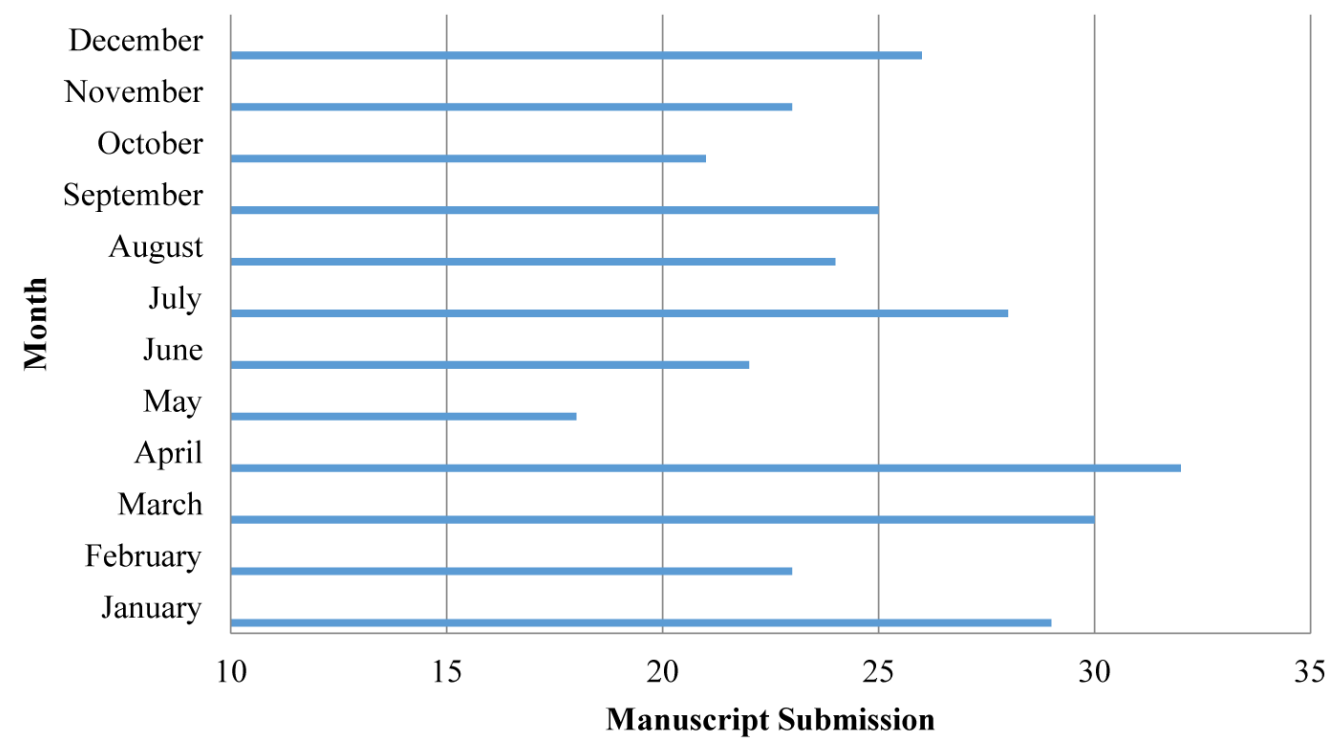

\begin{tabular}{lc}
\multicolumn{1}{c}{ Month } & Original \\
\hline January & 29 \\
February & 23 \\
March & 30 \\
April & 32 \\
May & 18 \\
June & 22 \\
July & 28 \\
August & 24 \\
September & 25 \\
October & 21 \\
November & 23 \\
December & 26 \\
\hline Total 2016 & $\mathbf{3 0 1}$ \\
\hline Source: https://mc.manuscriptcentral.com/maljms
\end{tabular}

Figure 1. Number of submissions via ScholarOne Manuscripts ${ }^{\mathrm{TM}}$ in 2016, grouped by month 


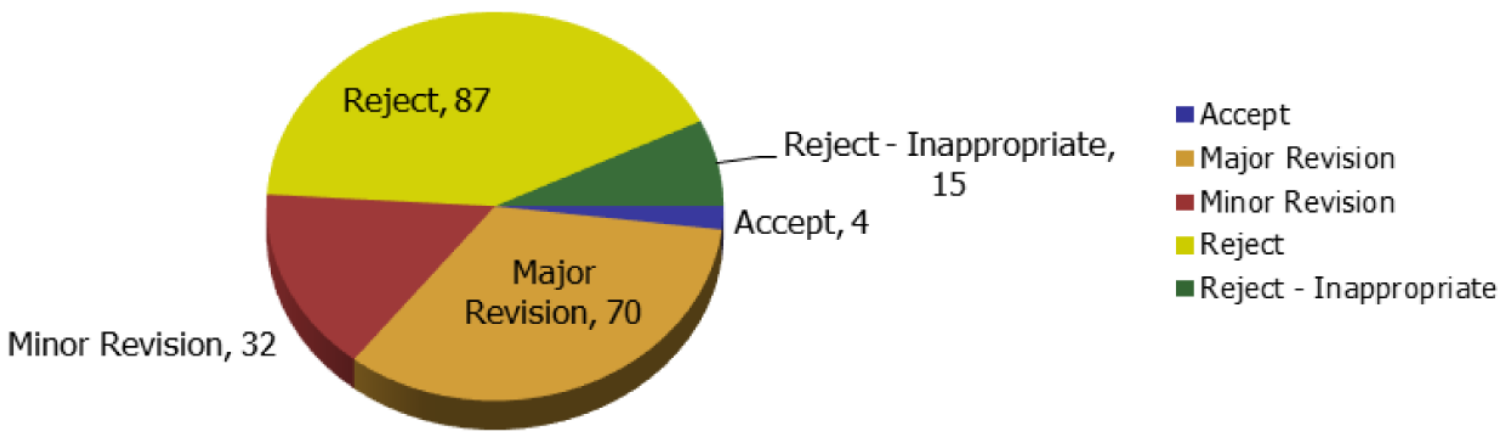

Figure 2. Information based on original manuscripts submitted and decided between Jan 1, 2016 and Dec 31, 2016

Source: https://mc.manuscriptcentral.com/maljms

of $87(41.8 \%)$ manuscripts were rejected, mostly due to their inferior research findings; 15 (7.2\%) were rejected due to their inappropriate scope of study.

\section{Inaugural Recognition}

In other new, the Ministry of Higher Education (MOHE) of Malaysia has initiated a new program called the Current Research in Malaysia (CREAM) award, first introduced in 2015. This award is accorded to Malaysian scholarly journals, published by Malaysian scholarly publishers, which have demonstrated remarkable performance based on a set of identified criteria outlined by the Malaysian Citation Centre (MCC). The CREAM award recipients are given incentives in the form of the Publication Encouragement Scheme. The main objectives of this award are:

1. to strengthen local journals in a way that would enable them to be indexed into international journal databases such as Scopus or WoS (Web of Science).

2. to ensure the indexed journals could remain in the database and thus help boost their citation impact factors.

The Malaysian Journal of Medical Sciences, for the first time, has been selected as the CREAM award recipient for 2016, under the Potential Journal category (3). follows:

The journal's performance in 2016 was as

- Source Normalised Impact per Paper (SNIP): 0.595

- SCImago Journal Rank (SJR): 0.28

- Citescore: 0.64

\section{Correspondence}

Ms Nour Azimah Zulkapli

BSc Biology (Hons) (USM)

Editorial Office,

Malaysian Journal of Medical Sciences,

Penerbit Universiti Sains Malaysia,

Universiti Sains Malaysia,

1180o USM, Pulau Pinang, Malaysia.

Tel: +604 6534448

Fax: +604 6575714

E-mail: mjms.usm@gmail.com

\section{References}

1. Zulkapli NA, Sobi S, Mohd Zubaidi NA, Abdullah JM. Malaysian Journal of Medical Sciences' publishing report (2014-2015). Malays $J$ Med Sci. 2016;23(4):1-4. doi:10.21315/ mjms2016.23.4.1

2. Malaysian Citation Centre. Performance of Malaysian Journals in MyCite: 2013. Putrajaya, Malaysia: Ministry of Education Malaysia; 2014

3. New Strait Times. USM's researchers, publications, shine at the Malaysia Rising Star Award. 2016. Retrieved Oct 20, 2017 from https://www.nst.com.my/news/2016/11/185094/ usms-researchers-publications-shine-malaysiarising-star-award 